Original Research Paper

\title{
Legislative Strengthening and Empowerment: Efforts to Strengthen Local Governance and Accountability through Provincial Parliaments in Indonesia
}

\author{
Cecep Darmawan \\ Faculty of Social Sciences Education, Universitas Pendidikan Indonesia, Indonesia
}

\author{
Article history \\ Received: 20-09-2015 \\ Revised: $20-10-2015$ \\ Accepted: 22-10-2015 \\ Email: cepupiwan@gmail.com
}

\begin{abstract}
This paper is about the performance of legislators at the provincial level in Indonesia. The study was conducted in the West Java Province to establish efforts made to strengthen local governments and improve accountability through provincial parliaments. There are several socio-polictical factors which make this research essential, among them include corruption, transparency and accountability, intellectual abilities and the legislature's responsibilities towards the communities represented by the different members of the assembly. To establish how empowerment influences the legislatures' performances, a survey method was used with a asystematic sampling technique. The data comprized of both the primary and secondary data which were collected through the study of documents, interviews, observations and with the use of questionnaires. The results revealed that the legislators of the West Java Parliament have different abilities. It was also established that legislature empowerment affects performance of individual legislators. In order to improve their performance, it is suggested that mobilization and cooperation can help.
\end{abstract}

Keywords: Empowerment, Legislator Empowerment, Provincial Parliament, Performance and Service Delivery

\section{Introduction}

Measures by governments, philathronpists and civil society alike to improve governance, accountability and development outcomes on the ground (Ringold et al., 2011) have led to various reforms in the different countries accross the glob. This lies in the assumption that for genuine development to take place, there is need to empower legitimate local institutions (HCIDC, 2015) including provincial legislators, in the effort to support a democracy. In this case, parliament plays a crucial role in development, since political parties which through parliaments greatly influence any country's development processes and change (DID, 2006).

Though it is a well known fact that with a strong parliament, democratization can be a good opportunity for (Andriana et al., 2012) development, in Indonesia, political parties rarely conduct capacity building for their cadres. This means that empowerment of legislators, more so at the middle and lower levels, including the provincial level require strengthening by introducing broader legisture and legislator strengthening programs (Johnson and Biddle, 2000). There is need to develop more effective legislative strengthening programs (Johnson and Biddle, 2000). For Indonesia, Legislature strengthening focuses on several issues, among them are: Improving accountability, budgetary capacity strengthening and competence improvement in regard to democractic prosesssions. In relation to this, provincial legislature system has become one of the points of focus. It is believed that Provincial Parliaments are key partner to a country's democracy and development. According to Mariana et al. (2005) the use of the rights owned by the Provincial Parliamentto make the provincial government accountable is an indicator that there isgood performance and service delivery of the legislatures.

In the case of the West Java Provincial Parliament, within the political period of 1999 to 2004, there were a number of indications of weaknesses by the Provincial Parliamentarians in excuting their lesgislative duties or functions. The weaknesses involved conflicts between the legislature and executive and also the over-spending by the parliamentarians, something which was considered uncomparable to both legislature and executive's performance. These weeknesses to some people are perceived as indicators of a failing 
democracy. Kapstein and Converse (2008) point out that performance, especially economic performance of the legislatures can lead to failure of a democracy.

In an effort to improve the quality of work of the legislatures, political parties are encouraged to run a program that aims to improve the performance of their cadres and to remind them that, if chosen they should remember to work as representatives of their constituences, as well as to increase the capacity and the capability of their knowledge, skills and insights on national politics. However, they should understand factors which influcence good democracy, hence influencing legislature performance, according to a (Scott and Mcloughlin, 2014) they suggest that factors which determine the quality and strength of democratic politics and what makes democracies susceptible to failure, include: Understanding or failure to understand citizens' concerns and core liberal norms of a democracy.

In order to strengthen the functioning of legislatures, the legitimate political institutions from the national, regional to local levels, including the Provincial Parliament, hae each provided equal opportunities to their legislatures in an effort to achieve the vision and mission of development in West Java. For instance, each year, legislatures are encouraged to engage in dialogue and communicate directly with their constituencies. However, at times new entrants in politics do not understand such issues which are to demcocratic politics.

\section{Literature Review}

\section{Empowerment in the Effort to Strengthen the Legislature}

The way empowerment sinterpreted differs from person to person. However, the most common point is that it involves change. According to Quinn (1996) empowerment is the preparedness of an individual or organization to initiate action. Whereas, Hadi et al. (2015) look at empowermment as the means to facilitate deeper and more harmonious form of development on an individual or organization. The latter look at empowerment from the economics and education perspective.

There are several dimensions of empowerment. The NWEC (2010) summarizes the dimensions of empowerment into five dimensions, including: Cognitive dimension-awareness and understanding of one's conditions; psychological dimension-regarding selfconfidence and self-esteem; economic dimension-the ability to access resources, to engage in productive activities and to take autonomous decisions.

The political dimension is about the ability to set one's own agenda, to negotiate, lead and organize for changing conditions NWEC (2010). Weissberg (1999) in his book on "The Politics of Empowerment" concludes that in contemporary perspective the term 'empowerment' does not hold meaning, because it hasalot of conflicting ideas, plans and goals' which, symbolize further dependency on government programs rather than self-determination. He therefore,argues that for advocates of empowerment tosucceed, should understand human condition (Weissberg, 1999). Based on Weissberg's arguement, Lamb (2000) argues that guenuine empowerment requires self-initiative of the people. The process requires more skills and managerial resources which need the use of a set of new skills as disclosed by Stewart (1994).

This is inline with the dimensions pointed out by NWEC (2010) which shows that empowerment requires the ability to ensure that every legislator has all the resources required to succeed. In all discussions, it has been noted that to empower legistures, an empowerment strengthening program is needed to facilitate the process. This is the most fundamental component required in the process of empowerment. Since legislator represent constituences, they are required to consult. With consultations, every member of the parliament is expected to work as a leader or manager in an organization which needs a consultant or experienced personal in the area of the services provided for a company to succeed.

Consultation is not only related to everyday life matters, but also related to strategic issues. In other words, as representatives of communities, the political representatives are expected to collaborate. Collaboration, according to Stewart (1994) is aboutcooperation between managers and staffs, if a final goal of anyempowerment program is to be achieved. According to Bachrach and Botwinick (1992) empowerment is a complex and comprehensive concept consisting of: The formulation of strategic goals and objectives by individuals and institutions; the mobilization of all resources through strategic interaction between individuals and institutions in order to obtain efficiency results; combining all resources at higher levels, including skills, capacities and networks, that aim to expand the access of empowerment; empowerment means pluralism and lso an institutional and individual network.

In the concept of empowerment, there are two sustaining variables, namely "freedom" that is owned by every legislator and "partnership" of Parliament as the legislature with the executive. Inline with the optimizing of the use of rights that are possessed by Provincial Parliament as stipulated by the (PRI, 2004) which makes it must, whereas, the variable of equality can be measured by the level of harmony between the executives (in this case the local government) with the legislature (Provincial Parliament) in performing theirgovernment duties, as expected by the public. 


\section{Performance}

In Indonesia, the National Administration body (Lembaga Administrasi Negara) as noted by Widodo (2001) formulates performance indicators which help to assess program and the achievement level of the setgoals, objectives and vision of the organization or government institutions. Stout as cited by (Tangkilisan, 2005) also suggests that the measurement or the assessment of organizational performance is a process to record and measure the achievement in the implementation of activities towards the mission accomplishment through the results that are displayed in the form of products, services, or even a process. Mangkunegara (2000) defines performance as "the quality and quantity of work result that are achieved by an employee in performing their duties, in accordance with the responsibilities given to him".

While, Dessler (1998) describes performance of anindividual as involving specific attitudes and behaviors to perform a certain duty. Based on some definitions mentioned above, it can be concluded that institutional performance is the result of a process of individual performance, in the form of actual behavior that is exhibited by an employee when carrying out his functions, roles and tasks.

Tangkilisan (2005; Lynch and Cross, 1995) suggest that there are several requirements in a system of effective organizational performance, namely: (1) It is based on each activity and characteristics of the organization itself, in accordance with the customer perspective, (2) an evaluation of various activities by using views and orientation on customer needs, (3) it requires a thorough assessment of the various aspects of the activity performance that affect customer satisfaction and (4) the performance of the organization should be known by all members of the organization as a feedback for them to recognize problems faced by the organization.

Nasir (2003; Whittaker, 1995) define performance as "a management tool that is used to improve the quality of decision making and accountability in order to assess the success or failure of the implementation of activities (programs), in accordance with the goals and the objectives set before in order to achieve the vision and mission of the institution." Levine et al. (1990) proposes three concepts that are usually used to measure performance in the public sector, among them is concepts is responsiveness-where government officials are required tomeet the demand and needs of communities.

\section{Research Methodology}

The method used in this study is anexplanatory survey. This methodis used to obtain facts and tries to describe the symptoms of the ongoing practices (Nazir, 1985), besides it is relatively short and non- interactiveand easy to conduct (Dana and Dana, 2005) compared to other methods. It is explanatory in nature. It is used to explain the causal relationship among variables that are being studied by testing a hypothesis.

This paper explains the causal relationship, between variables through hypothesis testing and also examines the effect of the hypothesized variables. The independent variable $(\mathrm{X})$ in this study is the empowerment of legislature of West Java Provincial Parliament, while the dependent variable (Y) is the performance of legislators of West Java Provincial Parliament.

By using a survey method, the data obtained prior to the statistical calculations were tested for validity and reliability. The validity testwas performed to test the accuracy of the instruments used and the reliability test was performed to test the reliability of the instruments and internal consistency.

\section{Research Hypothesis}

The research hypothesis included proposed factor affecting legislatures' empowerment in regard to performance at duty,which include: Formulating strategic goals and objectives, mobilizing resources, combining resources, developing an attitude of pluralism and building a cooperation network of institutions and individual legislatures.

\section{Results of the Research}

The Effect of Empowerment of the Legislatures

The structural model derived is:

$$
\begin{aligned}
& Y=0,2717 X_{1}+0,2831 X_{2} \\
& +0,1525 X_{3}+0,2773 X_{4}+0,0594 X_{5}
\end{aligned}
$$

Where:

$X_{1}=$ Formulating strategic goals and objectives variable

$X_{2}=$ Mobilizing resources

$X_{3}=$ Combining resources

$X_{4}=$ Developing an attitude of pluralism

$X_{5}=$ Building a cooperation network

$Y=$ Performance of Provincial Parliament

In the equation of the structural model, the path coefficient value of exogenous variables on endogenous variables is likely to be positive or negative. The positive path coefficient value means that the exogenous variables will increase the level of endogenous variables, while the negative path coefficient value means that the exogenous variables will reduce the level of endogenous variables. In the result of path analysis above all variables of empowerment of legislators of Provincial Parliament is positive, meaning that all the variables of empowerment of legislators of Provincial Parliament will have a positive influence on the performance of Provincial Parliament. 
From the result of path analysis, the value of path coefficient of sub variable formulating strategic goals and objectives $\left(X_{1}\right)$ on the performance of Provincial Parliament $(Y)$ equals to 0.2717 . While the value of path coefficient of mobilizing resources $\left(X_{2}\right)$, combining resources $\left(X_{3}\right)$, developing an attitude of pluralism $\left(X_{4}\right)$ and building a cooperation network $\left(X_{5}\right)$ each of them respectively equals to $0.2831,0.1525,0.2773$ and 0.0594. When only considering the variable of formulating strategic goals and objectives, while the other variables are held constant, the dimension of formulating strategic goals and objectives will improve the performance of Provincial Parliament by 0.2717 . Similarly, the variable of mobilizing resources $\left(X_{2}\right)$, combining resources $\left(X_{3}\right)$, developing an attitude of pluralism $\left(X_{4}\right)$ and building a cooperation network $\left(X_{5}\right)$ will improve the performance of Provincial Parliament respectively by $0.2831,0.1525,0.2773$ and 0.0954 .

\section{Discussion}

\section{Interpretation of the Empowerment of Legislators of West Java Provincial Parliament}

The phenomenon studied in this research is a model of empowerment carried out by political parties to their members who are elected to be legislators. In accordance with the purpose of this research, what will be discussed in this study is only concerned with the empowerment of Provincial Parliament carried out by political parties.

The empowerment that is carried out by political parties to the legislators is in a form of training of legal drafting, training of mass communication, political ethics, improvement of the insight and ideology of the party (the vision and mission of the party), improvement of the notion of value of the nation and state (the vision and mission of regional development) and the socialization of legislation and governmental systems.

Based on the information's and data, the legislators of West Java Provincial Parliament in the 1999-2004 period received training from their political parties variously, it was found that there is no uniformity in terms of model and material of empowerment carried out by each political party.

\section{Legislators Capability to Formulate Strategic Goals and Objectives}

In accordance with its authority, Parliament is the key in providing assurance that the power will not be abused. To achieve this goal every legislator, including the legislators of West Java Provincial Parliament, it is required to have the capability to formulate strategic goals and objectives.

From the data obtained, it can be concluded that the capability of legislators of West Java Provincial
Parliament to formulate strategic objectives varied. There are two groups in the legislators of Provincial Parliament, namely (a) group of legislators who is directly involved in the process of formulating the vision and mission of political parties and legislators, that is those coming from the group of cadres and (b) group of legislators who joins in the middle of the nomination period, that is generally coming from the group of artists, businessmen, academia, or government employees in which they understand the vision and mission of legislators, but they are not directly involved in the process of formulating the vision and mission in their political parties.

With regard to these aspects, there are several criteria used when formulating a political purpose. The first is the formulation of conceptual political vision. The second is the capability to capture the substance and priorities of political aspirations. The third is to formulate a strategy and a practical approach in realizing the political vision and missions. The last one is to empower the environmental resources to realize the political vision and missions. These four aspects become special parts in supporting the skill of political elite to be able to formulate political vision and mission.

\section{Interpretation of the Effect of Mobilizing Political Resources}

As a legislative body, West Java provincial Parliament has agencies or stakeholders in the form of fittings separately or as an organization partner. Through the council expectation of political mechanisms completeness, West Java Provincial Parliament can demonstrate good performance and the maximum in the fight for the aspirations of the people or in running regional development programs.

When compared with the first indicator, resource mobilization or political organization is an ability that has a very high value. A chairman of the board is able to mobilize political resources in the legislature to carry out and complete every council agenda. Similarly, the leaders of the factions in the West Java Provincial Parliament must condition their members to be able to carry out duties in accordance with the applicable regulations and procedures. Referring to the research data, it was found that the information on the five indicators studied, the highest the political skills possessed by members of the Legislative Council of West Java province the highest their ability to mobilize resources.

The ability to synchronize its resources and development of creativity in the political field is important to be possessed by members of the West Java Provincial Parliament as it relates to the conditions and nature of the people of West Java pluralistic and dynamic. Each community in West Java, including from the elite must 
understand the character of its people as a potential strategic diversity to build a better future in West Java.

\section{Interpretation of the Capability in Combining Resources}

Political vision and mission as well as political ideals can be realized by the political elites who have the ability to empower and conduct collaborative political resource. Having the ability to combine the resources of his organization into a demand for a member of Parliament is very important because it will affect the bargaining position of the board members in the presence of other political elite, executive, or the general public.

To gain political support, whoever the person or any political party needs to be able to utilize existing sources of social data as part of their political strategy. Political resources need to be carefully taken into account and can be used in an integrated way as a paradigm of cultural and political behavior in West Java, some of which are among the elite of religious or cultural values embedded and embraced by the community.

Although considered to be uneven, but some elite in the West Java Provincial Parliament are starting to use experts or academics to assist them in solving various issues on the agenda of the council. For the strengthening of Parliament is an absolute prerequisite for the development of democracy in the region, in order to build a national democracy.

When discussing about these issues, West Java Provincial Parliament also take advantage of academics as intellectual resources in order to obtain an analysis from the academic side associated with the interests of the people who are in charge, so it will not harm the interests of the people, nation and state. In support of regional development in West Java, academics, civil society organizations and social organizations have strategic potential as a political stakeholder Parliament.

\section{Attitudes and Behavior of Political Pluralism in the West Java Provincial Parliament}

From the results of a study about West Java Provincial Parliament during 2004-2009 period, it is proven an positive development of political culture. Urgency pluralist political stance is in line with the empirical condition that occurs in people of West Java.

West Java community Pluralism is also demonstrated by the emergence of Provincial Parliament elite who come from outside the province of West Java itself that is as much as $28 \%$ when seen from his birthplace. It shows that the appreciation of the public against the background of social and cultural diversity is open and participation from people outside the region sons have started to emerge.

Meanwhile, the results of this study found that the aspect of pluralism is closely related to the organization's ability to combine resources and political resources and build political cooperation. Statistics show that the ability to combine these resources has a high correlation to the attitude of pluralism. Similarly, the attitude of pluralism, this attitude has a positive correlation with the ability of the board in terms of working together.

\section{Ability in Building Cooperation in West Java Provincial Parliament}

Political cooperation is one important aspect that can support the political performance of board members. In the context of this study, a political cooperation can be built vertically or horizontally. In relation this point, Scott and Mcloughlin (2014) suggests that factors which determine the quality and strength of democratic politics and what makes democracies susceptible to failure, include: Understanding or failure to understand citizens' concerns and core liberal norms of a democracy. Nevertheless, it is interesting to observe the political behavior of cooperation that occurs at the level of West Java Provincial Parliament showed a unique phenomenon. Political elite, both individually and institutionally, show varied political cooperation behavior.

Based on the findings in this study, political cooperation or coalition that was built by the members of the board or of the party elite in fact did not show any consistent ideology or affiliation. Political cooperation that is built is more shake due to political interests of indiidual. In the perspective of this point, Weissberg (1999) concludes that in contemporary perspective the term 'empowerment' does not hold meaning, because it hasalot of conflicting ideas, plans and goals' which, symbolize further dependency on government programs rather than self-determination. As a result of the existence of this condition is a model of political cooperation shown by members of the West Java Provincial Parliament is not guided by a vision or goal of regional development in West Java, but rather based on the momentary interests of the political elite itself.

\section{Performance of West Java Provincial Parliament}

One of the problems that need a lot of attention of the wider community is linked to the performance of parliament. However, according to the theoretical framework of this research we evaluated aspects related to three general aspects, namely responsiveness, responsibility and accountability of the West Java Provincial Parliament. This point relates that of Stout as cited by (Tangkilisan, 2005) who suggest that the measurement or the assessment of organizational performance is a process to record and measure the achievement in the implementation of activities towards the mission accomplishment through the results that are displayed in the form of products, services, or even a process. 


\section{Interpretation Regarding Responsiveness}

Members of the board can be said responsive, if they are able to adopt the policies needed by the community, such as public opinion, the results of the poll, various forms of direct political behavior (such as demonstrations, rallies, wrote the reader and so on), or a political statement and a political platform on during the campaign. Whereas, Hadi et al. (2015) look at empowermment as the means to facilitate deeper and more harmonious form of development on an individual or organization. This implies responsibility goes in hand with individual change.

The proposal regarding the regulation is a privilege that attached to each member of the council, either because there is encouragement from the party, the aspirations of the community, or on its own initiative on the importance of a product in accordance with the requirements of legislation in the field. But until now board members tend to use party or awaiting proposals from the executive of the draft legislation so that the product legislation in West Java province is dominated by proposals emanating from the executive branch.

Such conditions give birth to the perception of the public that the products of West Java Provincial Parliament legislation is not motivated by the spirit in the wheels of government reform and development in West Java community, but rather leads to their economic interests brought about by the politicians. Interests that make products targeted legislation West Java Provincial Parliament is not in accordance with the agenda. At each year often there are remnants of the legislation that do not work can be completed thoroughly by the board members.

In this context, the responsiveness of legislators of West Java Province, against the public interest is very low. The quantity of product legislation does not reflect the high appreciation of the Parliament of the aspirations of the people. Some of the reasons put forward by members of the board is the high variation of aspirations of the people. The solution they implement is to find and prioritize the people's aspirations of each. Parliament was doing the selection were assessed in accordance with the aspirations of the public interest and the needs of the people of West Java.

This is done with the argument about the importance of selection aspiration through priority scale, the value of public interest, as well as the ability of local resources in realizing the aspirations of the people of West Java. However, the aspirations of the people in any form and on whatever is required by the board, at least to serve as a reference material as well as political considerations and academic consideration, so that it will appear a political policy that truly mature and comprehensive issued by the board.
For board members, regulation is a legal framework and legal basis for realizing the ideals of regional development. Formal shape aspirations of the people are in the form of development programs, while the regulation serves as the umbrella law in realizing the aspirations or ideals of development of West Java.

\section{Accountability and Responsibility}

Accountability or responsibility (accountability) in a political context by Salamm and Noor (2002) is a concept inherent in the theory and practice of democracy. Although the term is not very often used in theory, but the spirit of democracy itself aims to create a populist government that is based on "government of the people, by the people and for the people", where the context "for the people" most operational aspects in among which is the accountability of government to the people.

Responsibility (responsibility) is a concept pertaining to one's professional standards. State administration assessed responsible if the perpetrator has a professional standard or high technical competence. The principle of responsibility according to Tachyan (2008) is the conformity between the principles correct administration or in accordance with organizational policies, either explicitly or implicitly. In the measurement is done by matching the implementation of the activities and programs of the organization with administrative procedures and provisions that exist in the organization.

Subjective responsibility rooted in the nature of the individual subject apparatus (internal control) that emphasizes the ethical values and humanity, which is summarized in equity, equality and Fairless in providing services to the public and other administrative tasks. Therefore, subjective responsibility could also be interpreted to have a sense of responsibility (sense of responsibility) and have the ability and skills (capable to do or professionalism) sufficient in performing the duties, functions and responsibilities given to him.

Challenge perceptions elite West Java Provincial Parliament normative, showed that the behavior of a public official will always have political value. Therefore, as a result of the perception that they consider that there is no honesty in politics, there is only playing a devotional behavior for political purposes.

Poor government bureaucracy was related to the low responsiveness of legislators. Therefore, abuse of power and office to be subject under the spotlight of the public. In fact it can be said that the dysfunctional behavior so that became the source of many other behaviors. Behavior so that's the reason why an official leader of use that is not democratic managerial style.

Bureaucracy is often a major target for public dissatisfaction with public services provided by the 
government apparatus. In a further development the existence of the negative side of bureaucracy is caused by factors executor bureaucracy (apparatus). Therefore, in the study of bureaucracy it is known term pathology or disease bureaucratic red tape.

The legislature is responsible in the sense of "capable to do or professionalism" is required to have the ability to perform tasks and responsibilities given to him, both administratively and functionally. A public official can be said responsible if in carrying out their duties properly implemented and not just random, either there is control or not, by deploying all kinds of abilities and skills effectively and efficiently.

Political behavior displayed by the board of theWest Java Province show that the performance of the Provincial Parliament is more influenced by the aspects of resource mobilization, pluralism attitude development, formulation of strategic goals and objectives, rather than influenced by aspects combined resources and political cooperation. The difference between the value of the contribution of aspects of board members' ability to combine resources and political cooperation has the potential to cause delays in the development of democracy in West Java. The low value of the contribution in combining resources and political cooperation is evident in the effectiveness of the political work done by the members of the board, so it does not give a positive impact on development efforts in West Java.

Ability formulations strategic goals and objectives occupy third position in contributing to the performance of the political Parliament. There needs to be an educational effort aimed at improving the political intelligence of the members of the board, so they can do the formulations vision/mission and formulate political aspirations of the people.

Low ability of the political elite in the council in formulating the vision and mission can be associated with a political background and political experience each. Empowerment of the board can also be interpreted as an indication of the high rate of participation in political communication with the legislature. There are several obstacles faced by the public, making it difficult for them to conduct surveillance formally binding.

The first obstacle is formally no regulation which gives the opportunity to the public to conduct surveillance. The second obstacle is proportional electoral system conducted so far does not create a relationship between representatives and constituents. The third obstacle is the lack of recall system by the voters, so that the representatives of the people who sit in Parliament were not afraid to constituents. As a result there is a gap between the expectations of society with products produced by the Parliament. Last obstacle is political culture in the society which is not yet fully democratic. Therefore, Haryadi (2003) says that it is necessary and required for the members of the legislature in fact is the commitment, managerial capacity and sensitivity in absorbing aspirations, articulate interests, aggregate interests of the people and the like which becomes the function of the legislature. When analyzing the interaction between this phenomenon and the role of the representative body of the people responsible government building, Napitupulu (2005) expressed his critical view of the phenomenon of low performance of Parliament.

\section{Conclusion}

It has been established that the performance of the West Java Provincial Parliament legislature is influenced by the varying empowerment dimensions. The dimensions commonly inluencing the legislaturs include the resource mobilization dimensions which is greatly affecting the performance of the legistures.

Public control or public managment has emerged as one ot the concepts which is also serious influenced through empowerment. The Parliamentarians in turn are much influenced by the dimensions of public control which is commonly influenced by the mass media, political participation, political regulations and the party's internal regeneration system, as well as the pressure from interest groups and also general pressure groups.

\section{Acknowledgement}

In the process of writing this paper, I have been supported by many people, especially colleagues from the same department in the faculty of Social Science Education of Universitas Pendidikan Indonesia and also the University leadership. In addition, I also wish to extend my sincere thanks to all friends from other departments and faculties who have always encouraged me, Iam really grateful for all the support and prayers you have always offered me.

\section{Funding Information}

This research and publication has been funded by the Universitas Pendidikan Indonesia. I take this opportunity to thank the managment of Universitas Pendidikan Indonesia for the support provided.

\section{Ethics}

I wish to declare that all the required academic and research procedures have been followed. In case there is any loophole, then it is my faulty and not the faulty of the publisher. 


\section{References}

Andriana, N., S.N. Siregar, S. Haris, S. Yanuarti and A.P. Budiatri et al., 2012. Perempuan, partai politik, dan parlemen: Studi kinerja anggota legislatif perempuan di tingkat lokal. Lembaga Ilmu Pengetahuan Indonesia (LIPI) Pusat Penelitian Politik. Jakarta.

Bachrach, P. and A. Botwinick, 1992. Power and Empowerment: A Radical Theory of Participatory Democracy. 1st Edn., Temple University Press, Philadelpia, ISBN-10: 0877229392, pp: 211.

Dana, L.P. and T.E. Dana, 2005. Expanding the scope of methodologies used in entrepreneurship research. Int. J. Entrepreneurship Small Bus., 2: 79-88. DOI: 10.1504/IJESB.2005.006071

Dessler, G., 1998. Manajemen suber daya manusia jilid 2 , terjemahan benyamin molan, edisi Indonesia. Jakarta, Prenhalindo.

DID, 2006. Eliminating World Poverty, Making Governance Work for the Poor: A White Paper on International Development. 1st Edn., The Stationary Office, Norwich, ISBN-10: 0101687621, pp: 132.

Hadi, R., U. Wahyudin, J.S. Ardiwinata and W.J. Abdu, 2015. Education and microfinance: An alternative approach to the empowerment of the poor people in Indonesia, SpringerPlus, 4: 244-244.

DOI: $10.1186 /$ s40064-015-0995-6

Haryadi, 2003. Kedudukan dan Peranan Badan Legislatif Daerah. In: Kompleksitas Persoalan Otonomi Daerah Di Indonesia, Karim, D.A.G. (Ed.), Pustaka Pelajar, Yogyakarta, ISBN-10: 9793477059, pp: 402-402.

HCIDC, 2015. DFID's bilateral programme in Nepal: Government response to the committee's fourteenth report of session 2014-15. House of Commons International Development Committee.

Johnson, J.k. and J. Biddle, 2000. Understanding representation: Implications for legislative strengthening. Proceedings of the 2nd International Conference on Legislative Strengthening, (CLS' 00), Occasional Papers Series, USA: Center for Democracy and Governance, pp: 1-30.

Kapstein, E. and N. Converse, 2008. Why democracies fail. J. Democracy, 19: 57-68. DOI: $10.1353 /$ jod.0.0031

Lamb, K., 2000. Book review of 'the politics of empowerment' by robert weissberg. Social Contract J., 10: 272-272.

Levine, C.H., B.G. Peters and F.J. Thompson, 1990. Public Administration: Challenges, Choices, Consequences. 1st Edn., Scott Foreman, Illinois, ISBN-10: 0673399974, pp: 474.

Lynch, R. and K. Cross, 1995. Measure Up!: Yardsticks for Continuous Improvement. 1st Edn., Wiley, Cambridge, ISBN-10: 1557867186, pp: 250.
Mangkunegara, P., 2000. Manajemen Sumber Daya Manusia Perusahaan. 1st Edn., Remaja Rosdakarya, Bandung, ISBN-10: 9795149296, pp: 172.

Mariana, D., C. Paskarina and A. Bainus, 2005. Profil DPRD Provinsi Jawa Barat Periode 2004-2009. 1st Edn., Asosiasi Ilmu Politik Indonesia, Bandung, ISBN-10: 9799787629, pp: 100.

Napitupulu, P., 2005. Peran Dan Pertanggungjawaban DPR. 1st Edn., Alumni, Bandung, ISBN-10: 9794141003, pp: 432.

Nasir, S., 2003. Prosiding Seminar Nasional Pengukuran Kinerja Pemerintah Daerah. Fakultas Ekonomi, UAD, Yogyakarta, ISBN-10: 9799773725 , pp: 141.

Nazir, M., 1985. Metode penelitian. Ghalia Indonesia, Jakarta

NWEC, 2010. International forum for women's empowerment which took place in Tokyo on 9 october 2010. NWEC.

PRI, 2004. Undang-undang republik Indonesia nomor 32 tahun 2004 tentang pemerintahan daerah. Presiden Republik Indonesia.

Quinn, R.E., 1996. Deep Change: Discovering the Leader Within. 1st Edn., Wiley, San Francisco, ISBN-10: 0787902446, pp: 256.

Ringold, D., A. Holla, M. Koziol and S. Srivivasan, 2011. Citizens and Service Delivery: Assessing the Use of Social Accountability Approaches in Human Development Sectors. 1st Edn., World Bank Publications, Washington, DC., ISBN-10: 0821389300, pp: 148.

Salamm, A. and F. Noor, 2002. Pendahuluan, dalam akuntabilitas dalam otonomi daerah. Pusat Penelitianpolitik-LIPI, Jakarta.

Scott, Z. and C. Mcloughlin, 2014. Political systems: Topic guide, birmingham: GSDRC. University of Birmingham, UK.

Stewart, A.M., 1994. Empowering people. Pitman Publishing, London

Tachyan, 2008. Implementasi kebijakan publik. Truenorth, Bandung.

Tangkilisan, H.N.S., 2005. Manajemen Publik. 1st Edn., Grasindo, Jakarta, ISBN-10: 9797590453, pp: 345.

Weissberg, R., 1999. The Politics of Empowerment. 1st Edn., Greenwood Publishing Group, Westport, ISBN-10: 0275964264, pp: 255.

Whittaker, J.B., 1995. The government Performance and Results Act of 1993: A Mandate for Strategic Planning and Performance Measurement. 1st Edn., Educational Services Institut, Arlington, Virginia, ISBN-10: 0962619019, pp: 612.

Widodo, J., 2001. Good Governance: Telaah dari Dimensi AKuntabilitas dan Kontrol Birokrasi pada Era Desentralisasi dan Otonomi Daerah. 1st Edn., Insan Cendekia, Surabaya, ISBN-10: 9799408245, pp: 334. 